\title{
Antimicrobial activities and mode of action of the selected novel thienopyrimidines derivatives 2-[2-(diphenylmethylene) hydrazino]-5-isopropyl- -3-methylthieno [2, 3-d] pyrimidin-4-one
}

\author{
NADIA H. EL-BATANONY \\ University of Sadat City, Environmental Studies \\ and Research Institute (ESRI), Sustainable \\ Development of Environment and Management \\ its Projects Department, Sada City, Menoufiya \\ Governorate, Egypt \\ Correspondence: \\ Nadia H. El-Batanony \\ E-mail:nelbatanony@yahoo.com; \\ n.elbatanony@esri.usc.edu.eg \\ Key words: Antimicrobial, Mode of action, \\ Thieno[2,3-d]pyrimidinediones, lethal concentration
}

Received June 30, 2016.

Revised September 10, 2016.

Accepted September 11, 2016.

\begin{abstract}
Background and purpose: Although thienopyrimidines have an important antimicrobial efficacy, there is still a lack of understanding their antimicrobial mode of action. The current study aims to assess the antimicrobial activity of newly synthesized thienopyrimidines derivatives against some pathogens and to determine the mode of action of the most potent compound 2-[2-(diphenylmethylene) hydrazino]-5-isopropyl-3-methylthieno [2,3-d] pyrimidin-4-one (compound no. 20).
\end{abstract}

Materials and methods: Newly synthesized thieno[2,3-d]pyrimidinediones compounds examined for antimicrobial activity against pathogenic organisms by cut plug and viable cell counting method. The minimum inhibitory concentration (MIC) of (compound no. 20), it's mode of action; cytotoxicity and $L C_{50}$ were determined.

Results: One compound, compound no. 20 displayed potent activity. The growth inbibitory effect $(M / C)$ of the compound no. 20 differed among the tested strains. The inbibition becomes stronger; Candida albicans> Escherichia coli> Staphylococcus aureus. The MIC for all the tested microorganisms was $>50<100 \mu \mathrm{g} / \mathrm{mL}$. E. coli and C. albicans recorded highest value of potassium flow. Compound no. 20 affects oxygen consumption and exhibited cytotoxicity against $\mathrm{E}$. coli. LC50 value with brine shrimps was estimated at $48.736 \mu \mathrm{g} / \mathrm{mL}$ concentration.

Conclusion: It could be concluded that the mode of action of compound no.20 may be due to disruption of the cytoplasmic membrane by action upon the membrane potentials, permeability or net surface charge of the microbial membranes by its physicochemical characteristic. This led to leakage of cellular components and eventually cell death. This will lead to improved antimicrobial formulations and to ensure the prevention of the emergence of microbial resistance.

\section{INTRODUCTION}

R ecently, the problems of environmental pollution and health atRtracted considerable attention. The increasing appearance of resistant strain of pathogenic bacteria to the classical antimicrobial agents is rapidly represents an alarming threat to public health. The most commonly encountered antibiotic-resistant bacteria, methicillin-resistant $S$. aureus (MRSA), vancomycin-resistant Enterococci (VRE), and penicillin 
and cephalosporin-resistant Streptococci has had a major impact on infections in both the hospital and community setting (1). Thus, there is a pressing need for new efficacious antimicrobial agents that are capable of treating resistant bacterial strains.

Thienopyrimidines occupy a special position among fused pyrimidines compounds because they play an important role in diverse biological activities (2). A number of derivatives of these compounds display therapeutic activity as antimicrobial $(3,4)$, anti-inflammatory (5), analgesic activities (6), inhibition of cancer cell proliferation (7), antidiabetic (8) and prevention of cartilage destruction in particular diseases (6). Consequently, thienopyrimidines occupy a special position among these compounds. Thienopyrimidine derivatives are the one of outcome of the research in the field of therapeutic activity as antimicrobial (9). They are structural analogs of biogenic purines and can be considered as potential nucleic acid antimetabolites $(10,2)$.

In spite of the enormous antimicrobial activity of thienopyrimidines compounds and their derivatives that have been discovered, the mechanisms of action of these compounds are not yet reported (1). According to the reports of antimicrobial activity for structurally unrelated thienopyrimidinones, the biocides and antibiotics have multiple target sites within the microbial cell and the overall damage to these target sites results in the bactericidal effect. Since the emergence of bacterial resistance to biocides or antibiotics and the suggestion that biocide and antibiotic resistance in bacteria might be linked, it became an important issue to understanding the mechanism(s) of action of a biocide (11). Consequently we can consider the biocide and antibiotic mechanism(s) of action as a guide to understand the mechanism of action of thienopyrimidines compounds. Therefore, according to the bacterial structure; the overall mechanism(s) of action of any antimicrobial agents may be defined. Thus, there is three levels of interaction can be described: 1-interaction with outer cellular components; 2-interaction with the cytoplasmic membrane and 3 -interactionwith cytoplasmic constituents. Despite this, a biocide acts at one or all three levels of interaction with the bacterial cells to produce its antimicrobial activity (11).

The objective of this work was to study the antimicrobial activity of some newly synthesized thienopyrimidines derivatives and to investigate the mode of action of the most effective one, the compound no. 20 against Gram-positive, Gram-negative bacteria and pathogenic fungal species.

\section{MATERIALS AND METHODS}

\section{Synthesis of the thienopyrimidine derivatives compounds}

The thienopyrimidine derivatives compounds were synthesized and kindly given by Prof. Hamedet et al. (12)

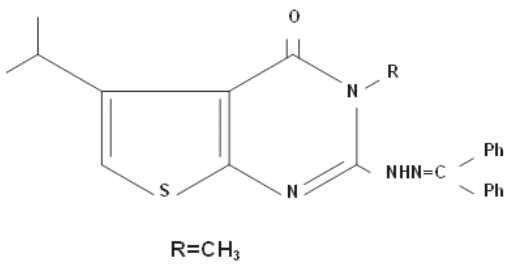

Figure 1. Structural formula of 2-[2-(diphenylmethylene) hydrazino]-5-isopropyl-3-methylthieno [2,3-d] pyrimidin-4-one (compound no. 20).

(Chemistry Department, Faculty of Science, Menoufiya University, Egypt). The thienopyrimidine molecular formula was $\mathrm{C}_{6} \mathrm{H}_{4} \mathrm{~N}_{2} \mathrm{~S}$. The procedures of the synthesis of these compounds were described in details by Hamedet al. (12). The chemical structure of the most potent derivative compound no. 20 was 2-[2-(diphenylmethylene) hydrazino]-5isopropyl-3-methylthieno [2, 3-d] pyrimidin-4-one. Its molecular formula was $\left(\mathrm{C}_{23} \mathrm{H}_{22} \mathrm{~N}_{4} \mathrm{OS}\right)$ as shown in Fig.1.

\section{Antimicrobial screening}

All the test organisms were obtained from the culture collection of the Microbiological Resource Center (MIRCEN), Faculty of Agriculture, Ain-Shams University, Cairo, Egypt.

\section{Antibacterial activity}

Two bacterial species represent both Gram-positive and Gram-negative strains were used to test the antibacterial activities of the target compounds: $S$. aureus as representative for the Gram-positive strains, while the Gramnegative strain was represented by $E$. coli. The bacteria were maintained on nutrient agar slopes.

\section{Antifungal activity}

Two pathogenic fungal species were used in the present study: Fusarium oxysporum and C. albicans. The fungi were obtained on czapek's Dox and sabouroud agar slopes, respectively.

\section{The agar diffusion method}

The antibacterial and antifungal activities of the synthesized compounds were screened against the following bacterial strains: $S$. aureus as representative for the Grampositive strains, while the Gram-negative strain was represented by $E$. coli and the following fungi: F. oxysporum and C. Albicans using the agar diffusion method (13). It was used to determine the antimicrobial activities of the prepared eleven thienopyrimidine compounds as described by El-Sayed et al. (2). The assay medium flasks containing 50 $\mathrm{mL}$ of media for each test organism. They were allowed to reach 40 to $50^{\circ} \mathrm{C}$ to be inoculated with $0.5 \mathrm{~mL}$ of the test organism cell suspension. The flasks were mixed well and poured each into a Petri dish $($ nine $\mathrm{cm}$ ) and allowed to 
solidify. After solidification, holes $(0.5 \mathrm{~cm}$ in diameter) were made in the agar plate by a sterile cork poorer. The solutions of synthesized target compounds were prepared by dissolving $20 \mathrm{mg}$ of each compound in two mL DMSO (Dimethyl sulfoxide). In these holes, $100 \mu \mathrm{L}$ of each compound was placed using an automatic micropipette. The Petri dishes were left at $5{ }^{\circ} \mathrm{C}$ for one hour to allow diffusion of the samples through the agar medium and retard the growth of the test organism. Plates were incubated at $30^{\circ} \mathrm{C}$ for $24 \mathrm{~h}$ for bacteria and $72 \mathrm{~h}$ of incubation at $28{ }^{\circ} \mathrm{C}$ for fungi. The antibiotic ampicillin trihydrate and the antifungal drug clotrimazole (Canasten) were used as positive controls, while DMSO was used as negative control. The diameters of inhibition zone were measured. The compounds which produced highest inhibition zone were further assayed at different concentrations in DMSO in order to quantify its inhibitory effect.

\section{Minimal inhibitory concentration (MIC)}

The minimum inhibitory concentration (MIC) is ,the lowest concentration of an antimicrobial that prevents the visible growth of a microorganism after overnight incubation". The importance of the MIC test is that it contains a semi-quantitative process which gives an approximation to the least concentration of antimicrobial agent needed to prevent microbial growth. The compound no. 20 showing reasonable inhibition zones $(\geq 20 \mathrm{~mm})$ were subjected to determine their minimal MIC value using the twofold serial dilution method recommended by the Clinical and Laboratory Standards Institute (14). The test organisms were grown in their suitable nutrient broth medium for bacteria and sabouraud's medium for fungi at $30{ }^{\circ} \mathrm{C}$ for $24 \mathrm{~h}$ for bacteria and $48 \mathrm{~h}$ at $28^{\circ} \mathrm{C}$ for fungi. Two fold serial dilutions of the test compound no. 20 were prepared using the proper nutrient broth to obtain concentrations $100,50,25$ and $12.5 \mu \mathrm{g} / \mathrm{mL}$. The broth tubes were seeded with the test bacteria $\left(6 \times 10^{4}\right) \mathrm{CFU} / \mathrm{mL}$ and $\left(8 \times 10^{2}\right)$ spores $/ \mathrm{mL}$ for the test fungi. The incubation period was for $24 \mathrm{~h}$ at $30^{\circ} \mathrm{C}$ for bacteria and $96 \mathrm{~h}$ at $28^{\circ} \mathrm{C}$ for fungi.

The growth was measured with the spread-plate (viable cell counting) method. After $24 \mathrm{~h}$ of contact, one $\mathrm{mL}$ portions were removed and mixed with nine $\mathrm{mL}$ of the full-strength nutrient broth; then, decimal serial dilutions were prepared from these dilutions, and the surviving bacteria or fungi were counted by the spread-plate method. After inoculation, the plates were incubated at $30{ }^{\circ} \mathrm{C}$ and the number of colonies was counted after $24 \mathrm{~h}$ for bacteria and after $48 \mathrm{~h}$ for fungi at $28^{\circ} \mathrm{C}$. The ratio of the colony numbers for the media containing the compound no. 20 and those without this compound (M/C) was taken as the surviving cell number, and with this value, the antimicrobial activity was evaluated (15).

\section{Leakage of potassium $\left(\mathrm{K}^{+}\right)$}

Leakage of potassium was assayed as a mean to study membrane damage caused by the compound no. 20 as described by Strauch et al. (16). The two tested bacterial species grown in nutrient broth medium at $30^{\circ} \mathrm{C}$ for 24 h. and the tested fungi grown in the broth sabouraud's medium at $28{ }^{\circ} \mathrm{C}$ for $96 \mathrm{~h}$. The cells of the test organisms were collected during exponential phase of growth by centrifugation, washed three times with $0.9 \%$ (wt. /vol) $\mathrm{NaCl}$ and finally resuspended in $20 \mathrm{~mL}$ of the same solution. The compound no. 20 was added at sublethal dose concentration $(50 \mu \mathrm{g} / \mathrm{mL})$ to aliquots of the cultures and shake for $30 \mathrm{~min}$. Samples (five $\mathrm{mL}$ ) were taken and centrifuged immediately at $6000 \mathrm{~g}$, and the supernatants were frozen. $\mathrm{K}^{+}$concentration was determined using a flame photometer (clinical flame photometer 410). Negative control sample was not treated with the compound no. 20 .

\section{Respiratory activity}

The quantity of oxygen consumed by the living cells (respiratory activity) in the presence or absence of the sublethal dose of the thienopyrimidine compound was determined as described by Tapia et al. (17). The living cells of the tested bacterial species and fungi grown up to exponential phase were harvested by centrifugation (6000 g), washed with saline solution and resuspended to a concentration of one $\mathrm{mg} / \mathrm{mL}$ cells (wet weight) in $50 \mathrm{mM}$ phosphate buffer ( $\mathrm{pH}$ 7.0).The cell suspension was added to a two $\mathrm{mL}$ chamber. The chamber then closed and incubated for five min. at room temperature with sublethal dose $(50 \mu \mathrm{g} / \mathrm{mL})$ of the compound no.20. Cell suspension without the sublethal dose of compound no.20 was used as control. The oxygen consumption was measured polarographically with oxygraph (Yellow Spring Instrument, Yellow Spring, OH, U.S.A.). The quantity of oxygen was determined as $\mu \mathrm{mol}$ of oxygen/mg wt. /h (18).

\section{In Vitro Cytotoxicity of the compound no.20 against $E$. coli}

The cytotoxicity of the compound no. 20 was detected using the biochemical induction assay (BIA).The biochemical induction assay (BIA) is a bacterial test system specifically responsive to agents that directly or indirectly initiate DNA-damage. The BIA uses an E. coli strain, in which the lacZ gene encodes $\beta$-galactosidase (LacZ). When the culture is treated with a DNA-damaging agent, the enzyme $\beta$-galactosidase is detected by a suitable chromogenic substrate (19).

In this test a plate containing $10 \mathrm{~mL}$ of nutrient agar was seeded by E. coli BR 315 and incubated at $30{ }^{\circ} \mathrm{C}$ for two days. The plates were spotted with sublethal dose (50 $\mu \mathrm{g} / \mathrm{mL}$ ) of the compound no.20. After three hours of incubation the plate is overlaid with a chromogenic substrate (a layer of agar containing 6-bromo-2-naphtyl $\beta$-Dgalactopyranoside). The production of red color around the test compound is used as an indication of DNA-damaging activity. 


\section{Effect of the compound no.20 on cell morphology of E. coli}

The test organism $E$. coli was treated with the sublethal dose $(50 \mu \mathrm{g} / \mathrm{mL})$ of the compound no.20. The morphology of $E$. coli was examined microscopically after being incubated for $24 \mathrm{~h}$. at $30^{\circ} \mathrm{C}$ (20).

\section{LC $_{50}$ Determination of compound no.20}

$\mathrm{LC}_{50}$ is the lethal concentration required to kill $50 \%$ of the population. This bioassay involves subjecting three replicate groups of individuals to a range of concentrations (or doses) of a toxic compound and measuring the mortality after a defined time interval. The data are then plotted and the $\mathrm{LC}_{50}$ is interpolated from the graph. Brine shrimps (Artemia salina) lethality bioassay was used to determine the $\mathrm{LC}_{50}$ of compound no. 20 according to the procedures described by $(21,22)$. The advantages of this method are being rapid results, reliability, inexpensive and convenient assay (21). Brine shrimps were hatched using brine shrimp eggs in a shallow rectangular dish filled with sea water(prepared using sea salt $38 \mathrm{~g} / \mathrm{L}$ and adjusted to $\mathrm{pH} 8.5$ using $1 \mathrm{~N} \mathrm{NaOH}$ ) under constant aeration. A plastic divider with several two $\mathrm{mm}$ holes was clamped in the middle of the dish to make two unequal compartments. The shrimp eggs were sprinkled into the larger compartment which was darkened while the smaller compartment was illuminated. After $48 \mathrm{~h}$ the phototropic hatching, active nauplii free from egg shells were collected from the illuminated compartment and used for the assay.

Stock solution of the compound no. 20 were prepared by dissolving $20 \mathrm{mg}$ of it in two $\mathrm{mL}$ of DMSO. Four different concentrations namely 10, 25, 50 and $100 \mu \mathrm{g} / \mathrm{mL}$, were prepared in triplicate from the stock solution. $0.5 \mathrm{~mL}$ of each concentration was added to vials each containing $4.5 \mathrm{~mL}$ of brine solution. Thirty nauplii (larva) were transferred through a glass capillary and placed in each vial. A control was prepared for the compound being assayed by adding $4.5 \mathrm{~mL}$ of sea water and $0.5 \mathrm{~mL}$ of DMSO. The shrimps that survived were counted after 24 hours. The total death and percentage mortality (death) at each dose level and control were determined. The $\mathrm{LC}_{50}$ value was calculated using the MS Excel 2007 to find regression equation ( $\mathrm{Y}=$ mortality; $\mathrm{X}=$ concentrations). The $\mathrm{LC}_{50}$ was derived from the best-fit line obtained (23).

\section{Effect of the compound no.20 on the total protein of the tested organisms}

The effect of the compound no.20 on total proteins of the tested organisms was determined using the method described by Lowery et al. (24). The molecular weight of $C$. albicans, E. coli and S. aureus protein were determined using SDS-polyacrylamide gel electrophoresis according to Laemmli (25).

\section{Statistical analysis}

The data were analyzed for statistical significance using analysis of variance (ANOVA) least significant difference (L.S.D) test at P value 0.05 (26). All the experiments were carried out in triplicate otherwise it will be indicated

\section{RESULTS}

\section{The antimicrobial activity of the tested thienopyrimidine compounds}

The obtained results in Table 1 suggested that the antimicrobial activities of the eleven tested compounds showed normal and mild activity in comparison to the reference drugs ampicillin trihydrate and the antifungal drug clotrimazole (Canasten). From the eleven prepared thienopyrimidine compounds, the compound no.20 was the most effective one on Gram negative, Gram positive bacteria and $C$. albicans. The diameter of inhibition zones produced by it ranged from 20 to $25 \mathrm{~mm}$ after $48 \mathrm{~h}$ of incubation for bacteria and $96 \mathrm{~h}$ for fungi. None of the eleven prepared thienopyrimidine compounds affect $F$. oxysporum.

\section{Minimal inhibitory concentration (MIC)}

The MIC of the compound no.20 result was illustrated in Fig.2. They showed that the inhibitory effect increased significantly by increasing in the concentration of

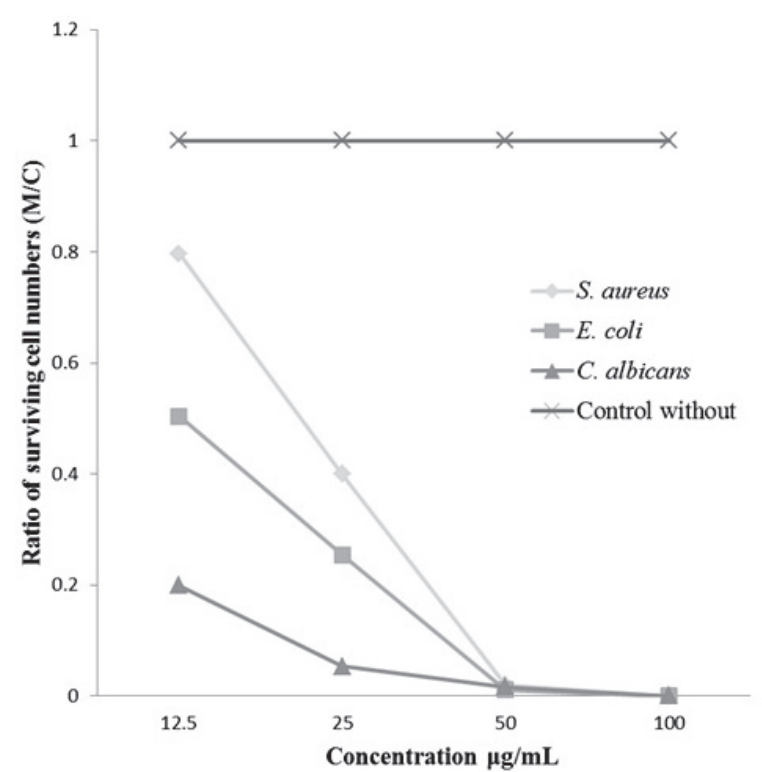

Figure 2. The antimicrobial activity evaluated by surviving cell numbers at different concentration of the compound no.20

M: The colony numbers for the media containing the compound no.20, C: The colony numbers for the media without the compound no.20. E. coli: Escherichia coli, S. aureus: Staphyloccous aureus, C. albicans: Candida albicans 
Table 1. The inhibitory effect of the tested thinopyrimidine compounds against different test bacteria on nutrient agar at $30{ }^{\circ} \mathrm{C}$ for $24 \mathrm{~h}$ and fungi on sabouroud agar at $28{ }^{\circ} \mathrm{C}$ for $96 \mathrm{~h}$ by the cut plugs method.

\begin{tabular}{|lcccc|}
\hline Thinopyrimidine compounds & \multicolumn{5}{c|}{ Diameter of inhibition zones (mm) } \\
\hline \multicolumn{5}{|c|}{ Tested organisms } \\
\hline 3 & E. coli & S. aureus & C. albicans & F. oxysporium \\
4 & nil & nil & nil & nil \\
5 & 12 & $12 \pm 0.5$ & nil & nil \\
7 a & nil & nil & nil & nil \\
8 & $6 \pm 0.4$ & $6 \pm 0.5$ & nil & nil \\
9 & nil & nil & nil & nil \\
10 a-h & nil & $12 \pm 0.3$ & nil & nil \\
11 a-h & nil & nil & nil & nil \\
$12 a$ & nil & nil & nil & nil \\
$14 a$ & nil & nil & nil & nil \\
20 & $20 \pm 0.3$ & nil & $20 \pm 0.2$ & nil \\
$22 \mathrm{a}-\mathrm{d}$ & nil & $25 \pm 0.2$ & nil & nil \\
\hline Ampicillin trihydrate & $20 \pm 0.3$ & nil & Not tested & nil \\
\hline Clotrimazole & Not tested & $22 \pm 0.3$ & $20+0.2$ & Not tested \\
\hline DMSO & nil & not tested & nil & 18 \\
\hline
\end{tabular}

E.coli: Escherichia coli, S. aureus: Staphyloccous aureus, C. albicans: Candida albicans, F. oxysporium: Fusarium oxysporium. Ampicillin trihydrate: antibacterial drug, Clotrimazole: antifungal drug. Nil: negative result (no inhibition). \pm : standard deviation of the means. DMSO: Dimethyl sulfoxide.

the compound no.20. The test organisms was failed to grow completely with $100 \mu \mathrm{g} / \mathrm{mL}$ concentration. Figure 2 proved that the MIC for all the tested microorganisms was $>50<100 \mu \mathrm{g} / \mathrm{mL}$. The growth inhibiting effect was quantitatively determined by ratio $(\mathrm{M} / \mathrm{C})$ of the surviving cell number, (M) in the medium containing the com-

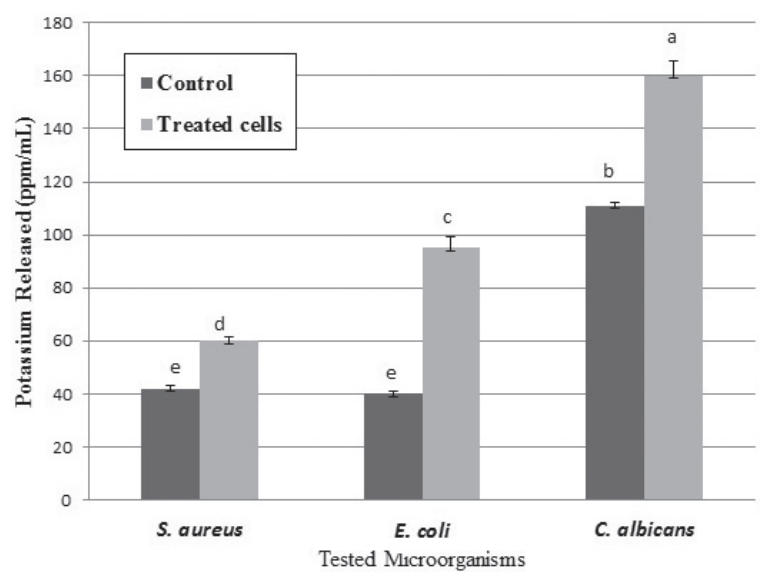

Figure 3. The amount of potassium released under the effect of the compound no. 20

Control: Sample was not treated with the compound no.20, Treated cells: Cells treated with the compound no.20 at concentration $50 \mu \mathrm{g} / \mathrm{mL}$ (sublethal dose). PPm: Part per million. The results are the mean $\pm S D(n=3)$. Means with the same letter are not significantly different. pound no.20 to that without it (C). As shown in Fig.2, the growth inhibitory effect of the compound no.20 differed among the bacterial strains. The inhibition becomes stronger in (decreasing order) C. albicans $>$ E.coli $>$ S. aureus.

\section{Leakage of potassium (K)}

The effect of the compound no.20 upon the membranes of $S$. aureus, E. coli and C. albicans as indicated by potassium $\left(\mathrm{K}^{+}\right)$leakage is shown in Fig. 3. This figure indicated that compound no. 20 has significant observable and marked leakage effects upon the tested organisms at $30 \mathrm{~min}$. The highest value of potassium flow was recorded with E. coli and C. albicans, whereas the least flow was noticed with $S$. aureus. The results with the Gram- negative organism showed that the compound no.20 released higher amounts of potassium ion than in the Gram- positive organism.

\section{Respiratory activity}

Figure 4. showed that the respiratory activity of E. coli, $S$. aureus and C. albicans cells treated or untreated with the tested compound no.20 was evaluated. The compound no. 20 at the sublethal dose has almost no effect on $S$. aureus cells respiration where it gives values comparable to the control. However with E. coli and C. albicans the sublethal dose of compound no.20 increased significantly the respiratory activity to somehow as shown in Fig. 4 in comparable to the control. 


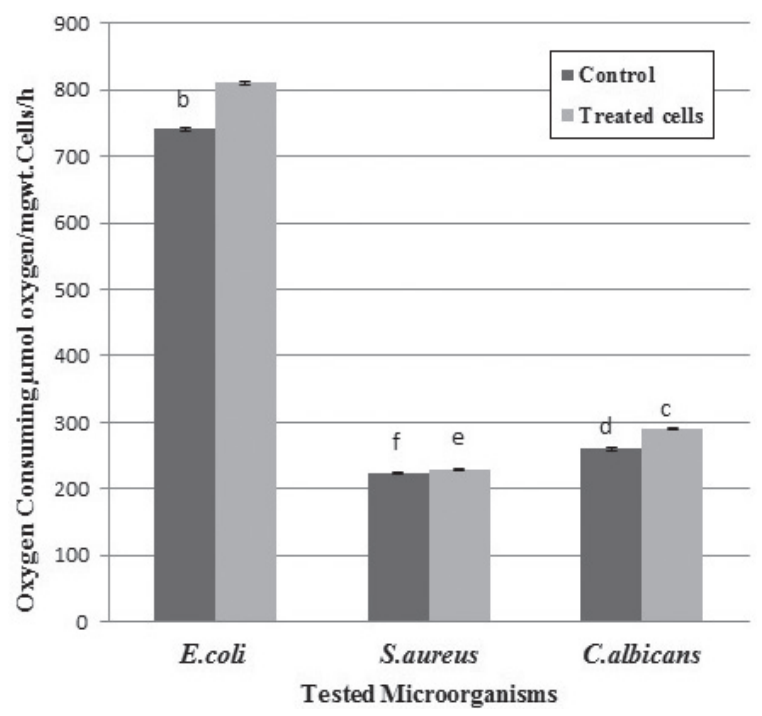

Figure 4. The amount of oxygen consumed by the tested microorganisms under the effect of the compound no.20.

Control: Sample was not treated with the compound no.20, Treated cells: cells treated with the compound no. 20 at concentration 50 $\mu g / m L$ (sublethal dose). The results are the mean $\pm S D(n=3)$. Means with the same letter are not significantly different.

\section{In vitro Cytotoxicity of the compound no.20 against $E$. coli}

The compound no.20 showed some cytotoxicity against DNA genome of E. coli, where it gives a brown color (positive result) indicating the hydrolysis of 6-bromo2-naphthyl $\beta$-galactopyranoside by $\beta$-galactosidase enzyme.

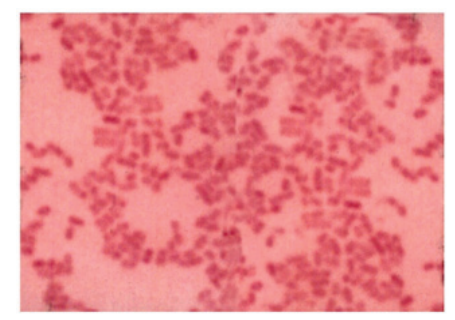

(A)

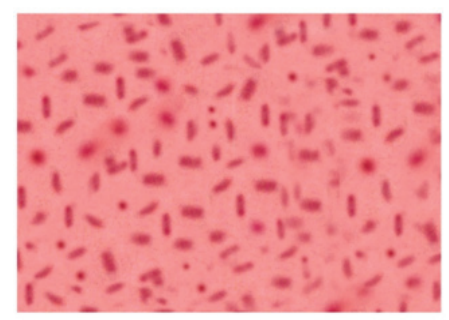

(B)

Figure 5. Effect of the compound no.20 on cell morphology of E. coli cells stained with gram stain and grown in nutrient broth with sublethal dose $(50 \mu \mathrm{g} / \mathrm{mL})$ under Light microscopy (1000x).

(A): Zero $\mu \mathrm{g} / \mathrm{mL}$, (B): $50 \mu \mathrm{g} / \mathrm{mL}$ (sublethal dose).

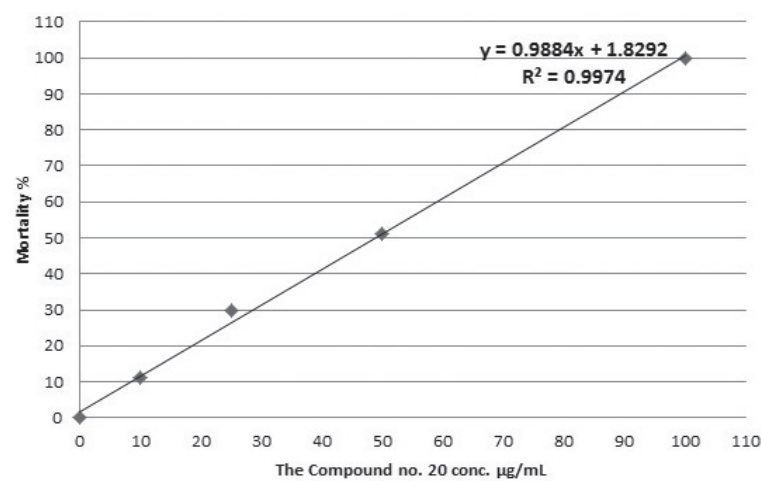

Figure 6. Mortality percentage (\%) curve of Brine shrimps (Artemia salina) nauplii exposed to different the compound no.20 concentrations for $24 \mathrm{~h}$.

\section{Effect of the compound no.20 on cell morphology of E. coli}

It was showed that the compound no.20 affect $E$. coli cell morphology, which was manifested as elongation and swollen of E. coli cells as shown in Fig.5.

\section{$L_{50}$ Determination of the compound no.20}

The procedure determines $\mathrm{LC}_{50}$ value in $\mu \mathrm{g} / \mathrm{mL}$ of the most effective compound no. 20 in the brine medium. The activity of the compound no. 20 was manifested as toxic agent to shrimps. Figure 6 gave the cytotoxicity results for the compound no.20. In Fig. 6 the result of regression analysis indicated that the mortality rate $(\mathrm{Y})$ is

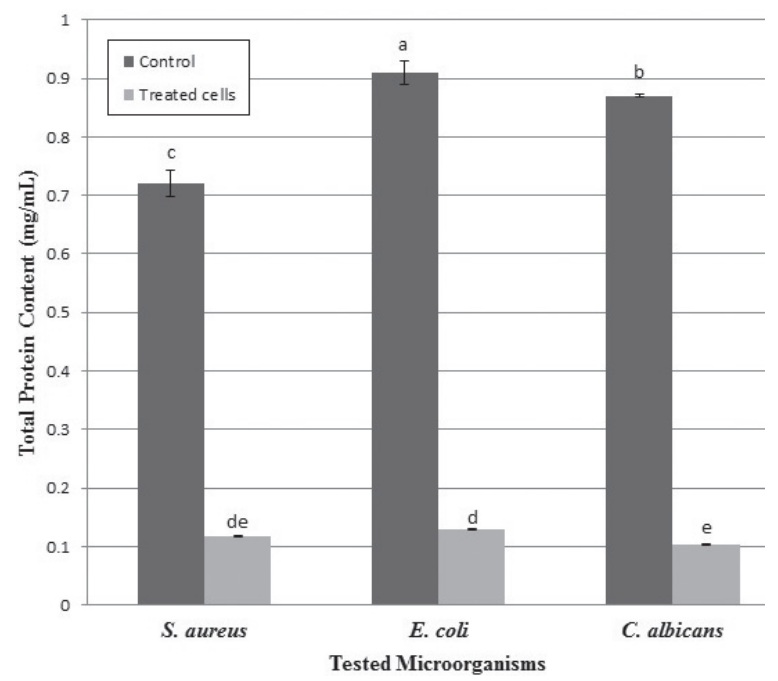

Figure 7. Effect of the compound no.20 on the total protein content $(\mathrm{mg} / \mathrm{mL})$ of the tested organisms.

Control: Sample was not treated with the compound no.20, Treated cells: cells treated with the compound no. 20 at concentration 50 $\mu g / m L$ (sublethal dose). The results are the mean $\pm S D(n=3)$. Means with the same letter are not significantly different. 


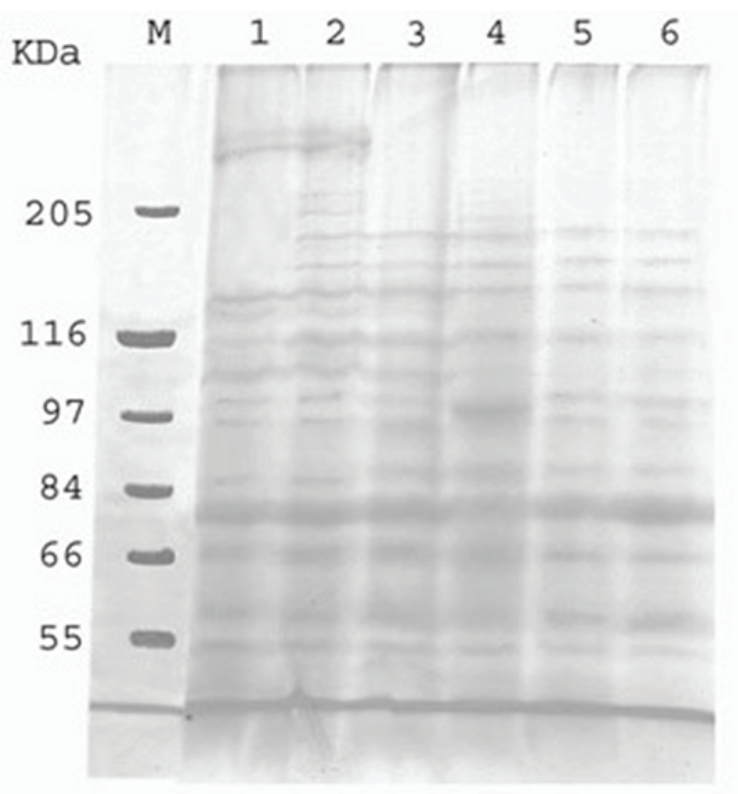

Figure 8. Protein banding patterns of tested organisms under the effect of the compound no.20 at $50 \mu \mathrm{g} / \mathrm{mL}$ at $10 \%$ SDS-Polyacrylamide gel electrophoresis.

Lanes: M: high molecular weight mass protein standard, 1: Protein pattern of untreated E. coli (control), 2: Protein pattern of $\mathrm{E}$. coli treated with the compound no.20, 3: Protein pattern of untreated S. aureus (control), 4: Protein pattern of S. aureus treated with the compound no.20, 5: Protein pattern of untreated C. albicans (control) and 6: Protein pattern of C. ablicans treated with the compound no.20.

positively correlated the concentration (X) having a regression coefficient $(\mathrm{R})$ close to one. The number of dead shrimps increased in response to increase in the compound no. 20 concentrations. An $\mathrm{LC}_{50}$ value of the compound no. 20 for brine shrimps was estimated at 48.736 $\mu \mathrm{g} / \mathrm{mL}$ concentration from the regression equation.

\section{Effect of the compound no.20 on the total protein of the tested organisms}

The amount of the total protein of E. coli, S. aureus and C. albicans cells treated with the compound no. 20 were decreased as compared with control as shown in Fig.7. Gel electrophoresis of the total protein indicated that there is a difference in protein banding pattern at 205-116 KDa in E. coli and also at $97 \mathrm{KDa}$ in $S$. aureus as compared with untreated cells. However, there is no difference in protein banding pattern in C.albicans treated with the compound no. 20 compared with untreated cells as shown in Fig.8.

\section{DISCUSSION}

\section{The antimicrobial activity of the tested thienopyrimidine compounds}

Although, thieno[2,3-d]pyrimidines had been extensively explored for their varied biological activity, the com- pounds reported here had not yet been prepared in previous literature. In this paper, the compound no. 20 possess abroad spectrum of antimicrobial activities. These results agreed with that obtained by many researchers $(27,3,28)$. The results indicated that thienopyrimidines are interesting heterocyclic compounds and a number of derivatives of these compounds display therapeutic activity as antibacterial and antifungal agents $(5,1,29,9)$.

\section{Minimal inhibitory concentration (MIC)}

The MIC of the compound no.20 for all the tested microorganisms was $>50<100 \mu \mathrm{g} / \mathrm{mL}$. Other researchers found that cyclopenteno and cyclohexeno [b]thieno[2,3d]-3,4-dihydropyrimidine-4-one displayed reasonable activity (MIC values $6.25-25 \mathrm{mg} / \mathrm{L}$ ) against both Grampositive and Gram-negative bacteria $(30,1)$. Chambhare et al. (3), proved that furanyl-thieno[2,3-d]pyrimidin-4ones displayed MIC values in the range of $4-100 \mathrm{mg} / \mathrm{L}$ against a collection of Gram-positive and Gram-negative microbe. Some novel thienopyrimidine and triazolothienopyrimidines showed MIC values in the range of $11-512 \mu \mathrm{g} / \mathrm{mL}$ (6). As well as, they also displayed antimicrobial activates towards the test organisms (Pseudomonas aeruginosa, S. aureus, Bacillus subtilis, E. coli, C. albicans and $C$. parapsilosis).It is obvious that the MIC depends mainly on the tested compound as well as used organisms. The growth inhibiting effect $(\mathrm{M} / \mathrm{C})$ obtained by Kenawy et al. (31) coincide with that of the compound no.20 in this study. They found that the growth inhibitory effect $\mathrm{M} / \mathrm{C}$ of polymer IX became stronger in the order of $B$. subtilis $<$ E. coli $<P$. aeruginosa $<$ a fungus (Trichophyton rubrum). Hence, the novel compound no.20 is considered as potent antibacterial agent $(2,32,33)$.

\section{Leakage of potassium (K)}

The treatment of Gram- negative and positive bacteria with the compound no. 20 at sublethal dose lead to release of higher amounts of potassium ion with the Gram- negative than the Gram-positive organism. Marked leakage of cytoplasmic material is considered indicative of gross and irreversible damaged to the cytoplasmic membrane (34).

\section{Respiratory activity}

The effect of the compound no. 20 on bacterial respiration was similar to that recorded with nisin on E. coli and S. aureus (35). Poly (chlorethyvinylether-co-vinylbenzoylchloride) increased respiration for $C$. albicans and $C$. tropicials (20) as that observed with the effect of the compound no. 20 on C. albicans respiration. This effect may be indicates that many chemical compounds interfering directly with electron transfer or uncoupled oxidative phosphorylation from electron transport. So, the aerobic synthesis of ATP is inhibited and the oxygen uptake is not inhibited (17). Also, it may be indicates a slight effect on 
the plasma membrane and increasing cells respiration for exhausting the energy compound present inside the cell before its death (20).

\section{In Vitro Cytotoxicity of the compound no.20 against $E$. coli}

The cytotoxic effect of the compound no.20 against $E$. coli coincide with that obtained by (11). They observed that the cytoplasmic membrane disruption is often exemplified by the leakage of intracellular components, potassium $\left(\mathrm{K}^{+}\right)$followed by inorganic phosphates, pool of amino acids and materials absorbing at $260 \mathrm{~nm}$, nucleic acids and proteins. Moreover, the compound no.20 changed cell morphology in E. coli cells. Saloman and Farias (36) found that microcin 25; a peptide antibiotic caused E. coli cell filamentation. Moreover, poly (methyl methacrylate co-vinylbenzoylchloride) altered cell morphology which was manifested as aggregated and swollen yeast cells $(C$. albicans ATTCC 2091) (20). Simôesc et al. (18) found that interference on bacterial cell cycle occurs at high ortho-phtalaldehyde concentrations and cell division is compromised as the cellular septation seems not to occur. Therefore, a cellular elongation takes place in $P$. fuorescens cells. Consequently, the formation of long forms of bacteria following antimicrobial treatment may be an indication of cell wall damage (11).

\section{LC $_{50}$ Determination of the compound no.20}

Compound no.20 is manifested as toxic agent to brine shrimps. The result of $\mathrm{LC}_{50}$ value of the compound no. 20 for brine shrimps coincides with many other studies. The $\mathrm{LD}_{50}$ values of the active compound of a series of 2-substituted amino-3-aminocyclopenteno or cyclohexeno[b] thieno[2,3-d]-3,4-dihydropyrimidin-4-ones ranged from $25-250 \mu \mathrm{g} / \mathrm{mL}$ (30). The cytotoxicity activity of the polar fractions of Cochlospermum tinctorium extracts using the brine shrimp lethality bioassay method were determined by linear regression analysis method and it was $240 \mu \mathrm{g} / \mathrm{mL}$ for $80 \%$ acetone extract and $437 \mu \mathrm{g} / \mathrm{mL}$ for $\mathrm{n}$-butanol extract (37). The compound no.20 showed potent biocide activity against brine shrimp due to their lower cytotoxicity that agreement with preliminary anti-microbial screening and the minimum inhibitory concentration (MIC). This finding is in agreement with that of Fayed and Ghanem (29).

\section{Effect of the compound no.20 on the total protein of the tested organisms}

The result obtained was in agreement with that obtained by Ali et al. (38). They found that treatments of MCF-7 cells with $1 / 10$ of $\mathrm{LC}_{50}$ of three thienopyrimidine derivatives decline the total protein, DNA and RNA content compared with MCF-7 cells harvested from control.

The protein banding pattern of $E$. coli and $S$. aureus treated cells with the compound no.20, give results agreed with many researchers $(39,40)$. They found that thienopyrimidine derivatives inhibits dihydrofolate reductase (DHFR) which plays an essential role in carbon metabolism, which is critical to the biosynthesis of DNA, RNA, and the essential amino acid methionine. However, the effect of the compound no. 20 on protein banding pattern in $C$. albicans coincide with that obtained with Mahmoud and Aly (20). They found that the effect of synthesized polymers modified poly (methylmethacrylate-co-vinylbenzoylchloride) and a modified linear poly (chloroethylvinylether-co-vinylbenzoylchloride) on C. albicans indicated no clear effects in the phosphopeptidomannan molecular weight with main bands at 45, 25 and $15 \mathrm{kDa}$. The only differences were in the protein concentrations.

Conclusion: it could be concluded that the compound no.20 has antimicrobial activity and cytotoxicity against the tested organisms. Moreover, the present results lead us to speculate that the compound no. 20 antimicrobial mode of action may be due to disruption of the cytoplasmic membrane which is often exemplified by the leakage of intracellular components, potassium $\left(\mathrm{K}^{+}\right)$followed by pool of amino acids and materials absorbing at $260 \mathrm{~nm}$, nucleic acids and proteins. It is generally accepted that the bacterial outer envelope is responsible for the different microbial responses to biocidal challenges (11). Active agent can induce damage to the cytoplasmic membrane by action upon the membrane potentials, bound enzymes or permeability and this lead to leakage potassium ion, and other cellular components and eventually cell death (41, 42, 43). Furthermore, anther speculation of mode of action is that, the physicochemical characteristic of the compound no. 20 may be match with lipid composition and net surface charge of the bacterial membranes. Therefore, this cause its penetration and membrane leakage subsequently, this process can change the morphology of the bacterial cell (34). Thus, the ultimate goal of study the mechanisms of action of antimicrobial compounds will help to improve the bactericidal activity of a product, to confirm that biocides are employed in the most advantageous manner and to ensure the prevention of the emergence of microbial resistance. Furthermore, understanding the target sites of the antimicrobial compounds will lead to improved antimicrobial formulations $(11,1)$.

\section{REFERENCES}

1. DEWAL MB, WANI AS, VIDAILLAC C, OUPICKÝ D, MICHAEL J, RYBAK MJ, FIRESTINE SM 2012 Thieno[2,3-d] pyrimidinedione derivatives as antibacterial agents. Eur J Med Chem 51: 145-153. https://doi.org/10.1016/j.ejmech.2012.02.035

2. EL-SAYED WA, LLI OM, ZYADA RAF, MOHAMED AA ABDEL-RAHMAN AH 2012 Synthesis and antimicrobial activity of new substituted thienopyrimidines, their tetrazolyl and sugar derivatives. Acta Pol Pharm Drug Res 69: 439-447.

3. CHAMBHARE RV, KHADSE BG, BOBDE AS, BAHEKAR RH 2003 Synthesis and preliminary evaluation of someN-[5-(2furanyl)-2-methyl-4-oxo-4H-thieno[2,3-d]pyrimidin-3-yl]-carboxamide and 3-substituted-5-(2-furanyl)-2-methyl-3Hthieno[2,3-d]pyrimidin-4-ones as antimicrobial agents. Eur J Med 
Chem 38: 89-100.

https://doi.org/10.1016/S0223-5234(02)01442-3

4. ASHALATHA BV, NARAYANA B, RAJ KKV, KUMARI NS 2007 Synthesis of some new bioactive 3-amino-2-mercapto-5, 6, 7, 8-tetrahydro 1 benzothieno 2, 3-d pyrimidin-4(3H)-one derivatives. Eur J Med Chem 42: 719-728.

5. ALAGARSAMY V, MEENA S, RAMSESHU KV, SOLOMON VR, THIRUMURUGAN K, DHANABAL K, MURUGAN M 2006 Synthesis, analgesic, anti-inflammatory, ulcerogenicindex and antibacterial activities of novel 2-methylthio-3-substituted-5, 6, 7, 8-tetrahydrobenzo (b) thieno[2,3-d]pyrimidin-4(3H)-ones. Eur J Med Chem 41: 1293-1300.

https://doi.org/10.1016/j.ejmech.2006.06.005

6. SHETTY NS, LAMANI RS, KHAZI IAM 2009 Synthesis and antimicrobial activity of some novel thienopyrimidines and triazolothienopyrimidines. Journal of Chemical Sciences. 121: 301307. https://doi.org/10.1007/s12039-009-0034-7

7. JENNINGS LD, KINCAID SL, WANG YD, KRISHNAMURTHY G, BEYER CF, MGINNIS JP, MIRANDA M, DISCAFANI CM, RABINDRAN SK 2005 Parallel synthesis and biological evaluation of 5, 6, 7, 8-tetrahydrobenzothieno [2,3-d] pyrimidin- $4(3 \mathrm{H})$-one cytotoxic agents selective for p21-deficient cells. Bioorg.Med.Chem Lett 15: 4731-4735.

https://doi.org/10.1016/j.bmcl.2005.07.072

8. DENG JF, PENG L, ZHANG GC, LAN XB, LI CF, CHEN FX, ZHOU YY, LIN ZX, CHEN L, DAI RK, XU HJ, YANG L, ZHANG XQ, HU WH 2011 The highly potent and selective dipeptidyl peptidase IV inhibitors bearing a thienopyrimidine scaffold effectively treat type 2 diabetes. Eur J Med Chem 46: 71-76. https://doi.org/10.1016/j.ejmech.2010.10.016

9. TOCHE RB, NIKAM P 2015 Synthesis and evaluation of antimicrobial and antitubercular activity of arylidenehydrazines of indenothieno[2,3-d]pyrimidine. Chemistry \& Biology Interface. 5: 246-257.

10. LITVINOV VP 2004 Thienopyrimidines: synthesis, properties, and biological activity. Russian Chemical Bulletin, International Edition 53: 487-516.

https://doi.org/10.1023/B:RUCB.0000035630.75564.2b

11. MAILLARD JY 2002 Bacterial target sites for biocide action. Journal of Applied Microbiology Symposium Supplement 92: 16S27S. https://doi.org/10.1046/j.1365-2672.92.5s1.3.x

12. HAMED AA, ZEID IF, EL-GANZORY HH, ABDEL AAL MT 2008 Synthesis and structure of some thienopyrimidine derivatives. Monatsh Chem 139: 809-820. https://doi.org/10.1007/s00706-007-0823-y

13. JAIN SR, KAR A 1971The antibacterial activity of some essential oils and their combinations. Planta Med 20: 118-123. https://doi.org/10.1055/s-0028-1099675

14. CLSI 2015 Performance standards for antimicrobial susceptibility testing; twenty - fifth informational supplement, Clinical and Laboratory Standard Institute Wayne, Pennsylvania USAM100S25 35:1-231.

15. KENAWY E, ABDEL-HAY FI, EL-SHANSHOURY AR, ELNEWEHY MH 1998 Biologically active polymers: synthesis and antimicrobial activity of modified glycidyl methacrylate polymers having a quaternary ammonium and phosphonium groups. J Control Release 50: 145-152. https://doi.org/10.1016/S0168-3659(97)00126-0

16. STRAUCH E, KASPAR H, SCHAUDINN C, DERSCH P, MADELA K, GEWINNER C, HERTWIG S, WECKE J, APPEL B 2001Characterization of Enterocoliticin, a Phage Tail-Like Bacteriocin, and Its Effect on Pathogenic Yersinia enterocolitica Strains. Appl Environ Microbiol 67: 5634-5642. https://doi.org/10.1128/AEM.67.12.5634-5642.2001

17. TAPIA L, TORRES J, MENDOZA L, URZUA A, FERREIRA J, PAVANI M, WILKENS M 2004 Effect of 13-epi-Sclareol on the bacterial Respiratory Planta Medica 70: 1058-1063. https://doi.org/10.1055/s-2004-832647

18. SIMÔES M, SIMÔES LC, CLETO S, MACHADO I, PEREIRA MO, VIEIRA MJ 2007Antimicrobial mechanisms of ortho-phthalaldehyde action. J Basic Microbiol 47: 230-242. https://doi.org/10.1002/jobm.200610280

19. SINGH MP, ARIAS DA, GREENSTEIN M 2005Chemiluminometric biochemical induction assay (CBIA) for the detection of DNA-damaging agents. J Microbiol Methods 61: 277-280. https://doi.org/10.1016/j.mimet.2004.11.011

20. MAHMOUD YAG, ALY MM 2004 Anti-Candida and mode of action of two newly synthesized polymers: a modified poly (methylmethacrylate -co-vinylbenzoylchloride) and a modified linear poly (chloroethylvinylether-co-vinylbenzoylchloride) with special reference to Candida albicans and Candida tropicalis. Mycopathologia 157: 145-153. https://doi.org/10.1023/B:MYCO.0000020593.75809.91

21. MAYER BN, FERRIGNI N R, PUTNAM JE, JACOBSEN L B, NICHOLS DE, MCLAUDHLIN JL 1982 A convenient bioassay for active plant constituents. Planta Med 45: 31-34. https://doi.org/10.1055/s-2007-971236

22. JAKI B, ORJALA J, BURJI HR, STICHER O 1999 Biological screening of cyanobacteria for antimicrobial and molluscicidal activity, brine shrimp lethality, and cytotoxicity. J Pharm Biol 37: 138-143. https://doi.org/10.1076/phbi.37.2.138.6092

23. KUÇUKGUL GA, ALTINTERIM B, AKSU O 2013 Determination of lethal concentration (LC50) values of Cinnamomum zeylanicum hydrosol on carp fish. Iran J Fish Sci 12: 34-44.

24. LOWERY OH, ROSEBROUGH NJ, FARR AL, RANDELL RJ 1951Protein measurements with the folin phenol reagent. J Biol Chem 19: 265-275.

25. LAEMMLI UK 1970 Cleavage of structural proteins during the assembly of the head bacteriophage T4. Nature 227: 680-685. https://doi.org/10.1038/227680a0

26. SNEDECOR, GW, COCHRAN, WG 1980. Statistical Methods. Iowa State Univ. Press, USA.

27. HOZIEN ZA, ATTA FM, HASSAN KM, ABDEL-WAHAB AA, AHMED SA 1996 Synthesis and application of some new thienopyrimidine derivatives as antimicrobial agents. Synth Commun 26: 3733-3755. https://doi.org/10.1080/00397919608003791

28. EID FA, ABD EL-WAHAB AHF, EL-HAG ALI GAM, KHAFAGY MM 2004 Synthesis and antimicrobial evaluation of naphtha [2,1-b]pyrano[2,3-d]pyrimidine and pyrano[3,2-e][1,2,4] triazolo[1,5-c]pyrimidine derivatives. Acta Pharm 54: 13-26.

29. FAYED AA, GHANEM S 2013Anti-microbial evaluation of new thiazolopyrimidine derivatives. European Scientific Journal 9: 184197.

30. EL-SHERBENY MA, EL-ASHMAWY MB, EL-SUBBAGH HI, EL-EMAM AA, BADRIA FA 1995 Synthesis, antimicrobial and antiviral evaluation of certain thienopyrimidine derivatives. Eu J Med Chem 30: 445-449. https://doi.org/10.1016/0223-5234(96)88255-9

31. KENAWY E, ABDEL-HAY FI, SHAHADA L, EL-SHANSHOURY AR, EL-NEWEHY MH 2006 Biologically Active Polymers IV. Synthesis and Antimicrobial Activity of Tartaric Acid Polyamides. J Appl Polym Sci 102: 4780-4790. https://doi.org/10.1002/app.24126

32. JABLI D, LAHBIB K, DRIDI K, EFRIT ML 2015 Antibacterial Study Novel 2-cyanomethylthieno [3,2-e] [1,2,4]- triazolo[1,5-c] pyrimidine. J Pharm Chem Biol Sci 3: 178-187.

33. NAGARAJU K, HARIKRISHNA N, VASU V, RAO CV 2015 Synthesis and biological activity of novel bis and mono heterocycles of thienopyrimidine derivatives. Indo Am. j. pharm. Res. 5: 16041612. 
34. MIKSUSANTI M, JENIE BS, PRIOSOERYANTO BP, SYARIEF R, REKSO GT 2008 Mode of action Temu Kunci (kaempferia pandurata) essential oil on E. coli k1.1 cell determined by leakage of material cell and salt tolerance assays. Hayati Journal of Biosciences: 56-60.

35. DEMELO AMC, COOK GM, MILES RJ, POOL RK 1996 Nisin stimulates oxygen consumption by Staphylococcus aureus and Escherichia coli. Appl Environ Microbiol 62: 1831-1834.

36. SALOMAN AR, FARIAS NR 1992 Microcin 25 a novel antimicrobial peptide produced by Escherichia coli. J Bacteriol 174: 74287435. https://doi.org/10.1128/jb.174.22.7428-7435.1992

37. MUSA AA 2012 Cytotoxicity activity and phytochemical screening of Cochlospermum tinctorium Perrex A. Rich Rhizome. J App Pharm Sci 02: 155-159. https://doi.org/10.7324/JAPS.2012.2723

38. ALI MM, MAHMOUD AE, RASHAD AE 2011 Inhibition of human $\mathrm{MCF}_{\neg-7} 7$ breast cancer growth by free radicals enhancement of polycondensedthienopyrimidine derivatives. Asian J Pharm Clin Res 4: 118-122.

39. DONKOR IO, SHERRY HL, QUEENER SF 2003 Synthesis and DHFR inhibitory activity of a series of 6-substituted-2,4-diami- nothieno [2,3-d] pyrimidines. Eur J Med Chem: 605-611. https://doi.org/10.1016/S0223-5234(03)00101-6

40. MUNCHHOF MJ, BEEBE JS, CASAVANT JM, COOPER BA, DOTY JL, HIGDON CH, HILLERMAN SM, SODERSTROM CI, KNAUTH EA, MARX MA, ROSSI AMK, SOBOLOV SB, SUN J 2003Design and SAR of thienopyrimidine and thienopyridine inhibitors of VEGFR-2-kinase activity. Bioorg Med Chem Lett 14: 21-24. https://doi.org/10.1016/j.bmcl.2003.10.030

41. GILBERT P, PEMBERTON D, WILKINSON DE 1990 Barrier properties of the Gram-negative cell envelope towards high molecular weight polyhexamethylenebiguanides. J Appl Microbiol 69: 585-592. https://doi.org/10.1111/j.1365-2672.1990.tb01552.x

42. AL-ADHAM ISI, DINNING AJ, EASTWOOD IM, AUSTIN P, COLLIER PJ 1998 Cell membrane effects of some common biocides. J Ind Microbiol Biotechnol 21: 6-10. https://doi.org/10.1038/sj.jim.2900554

43. Kurdi P, Kawanishi K, Mizutani K, Yokota A 2006 Mechanism of Growth Inhibition by Free Bile Acids in Lactobacilli and Bifidobacteria. Bacteriol 188: 1979-1986.

https://doi.org/10.1128/JB.188.5.1979-1986.2006 